Nadwa : Jurnal Pendidikan Islam

Vol. 12, Nomor 1 Tahun 2018

Accredited by Ristekdikti based on Decree No. 51/E/KPT/2017

\title{
The Leadership of the Head Madrasah Based Quality
}

Wahyudi

Universitas Islam Negeri Walisongo Semarang

wahyudi@walisongo.ac.id

DYP Sugiharto

Universitas Negeri Semarang

Masrukhi

Universitas Negeri Semarang

Ahmad Rifai Rc

Universitas Negeri Semarang

\begin{abstract}
The research focus is to discuss about a leadership of the head madrasah-based quality in Madrasah Aliyah Al Mukmin Muhammadiyah, Tembarak, Temanggung, Central Java. It was used qualitative research. The result shown that the head of the madrasah had a strong desire to realize the vision and mission of the madrasah. He strongly built the quality culture of madrasah based on five principles. There are (1). always being a mukmin and Muslim everywhere and anytime. (2). always friendly in service. (3). having a high professionalism in carrying out administrative duties and adoring the work. (4). creative, dynamic, and innovative in scientific development, and (5). Behave and trustworthy manner, akhlaqul karimah and be role model to other academic community.
\end{abstract}

Keywords: Leadership; Madrasah's Headmaster; and Based-Quality;

\begin{abstract}
Abstrak
Fokus penelitian adalah untuk membahas tentang kualitas kepemimpinan kepala madrasah di Madrasah Aliyah Al Mukmin Muhammadiyah, Tembarak, Temanggung, Jawa Tengah. Metode penelitian menggunakan penelitian kualitatif. Hasilnya menunjukkan bahwa kepala madrasah memiliki keinginan yang kuat untuk mewujudkan visi dan misi madrasah. Dia sangat membangun budaya kualitas madrasah berdasarkan lima prinsip. (1). selalu menjadi seorang mukmin dan Muslim di mana saja dan kapan saja. (2). selalu ramah dalam pelayanan. (3). memiliki profesionalisme yang tinggi dalam menjalankan tugas-tugas administrasi dan mengagumi pekerjaan. (4). kreatif, dinamis, dan inovatif dalam pengembangan keilmuan, dan (5). berperilaku dan dapat dipercaya, akhlaqul karimah dan menjadi teladan bagi komunitas akademis lainnya.
\end{abstract}

Kata Kunci: Kepemimpinan; Kepala Sekolah Madrasah; dan Kualitas; al Mukmin 


\section{Introduction}

The various change-society and multi dimensional crises were attack Indonesian for a long time, as well as advances in information technology, which human beings can not escape with social media. These situations make difficult to found an ideal headmaster who has a high commitment in duty and responsibility. In many areas, there were many headmasters who had less mandate in conducted the leadership's duties. Similarly in education, not a few headmasters of education were amateur. The majority of the leaders did not have a clear vision and mission of educational institutions or schools who leads. 1 The conditions become negative impacts for school institutions, especially in the field of school climate and culture. The headmasters, who are not qualified in the organization, could not developed their leads.

This researcher conducts this to explain how the leadership of the head madrasah-based quality in Madrasah Aliyah Al Mukmin. Leadership is an important issue for an institutional group or organization. This happened because leadership is one of the factors had great affect in realizing the organization's goal. The headmasteris had an ability to influence the people behaviors in their workby authority. Authority is the ability to direct and influence subordinates in relation in conducting duties.2

Therefore, the leadership school-quality is crucial in achieving the school. The research by masters of educational management concluded that the quality of school gave influenced to the headmaster's leadership. There were 3 criteria in headmasters-based quality: (1) are able to create a conducive atmosphere for students to learn, (2) teachers engage and develop personally and professionally, and (3) the whole community provides support and high expectations. The school can be entitled successfully if the headmaster should cultivate the school by the third things has been stated. The Blumberg and Greenfield theses were used in various country with different geographic and

${ }_{1}$ H.E. Mulyasa, Manajemen \& Kepemimpinan Kepala Sekolah, (Jakarta: Bumi Aksara, 2012), p.17.

2Nanang Fatah, Landasan Manajemen Pendidikan, (Bandung, Remaja Rosda Karya, 1999), p.19. 
cultural, but these three things had been found although the headmaster have different policy. 3

Leadership is important aspect in organization. It has been activator of change and management activity. The leadership can exist not only as a symbol of organization, but also give positive effect to the organization development. The leadership is existing when he/she carry out the leadership's function in dealing by setting the goals of utilizing subordinates through participatory approach and professional leadership as indication of organizational leadership. 4

One of the efforts is optimization of the principal's role. The function of headmaster as a leader is to motivate the subordinates in achieving the teacher's performance, developing the vision and mission, and expanding their knowledge. Besides, the teacher also needs to expand their professional skills in planning, organizing, conducting and supervising the implementation of education, teacher must be able to innovate, develop, raise the trust, and are able in confronting status quo as the future challenge.5 According to Mulyadi, Edmond highlight that schools is need to improve their achievement, like the leader's performance who led with a good principal. Edmonds also argued that a dynamic organization is always led by a good leader.6 At least, it can be able to serve as an educator, manager, administrator, supervisor, leader, innovator, and motivator.7

Other factor is to encourage schools to realize their school vision, mission, goals and objectives through programs implemented in a planned and gradual manner. Therefore, the headmaster must have the ability of management, strategy, and

3Buchari Alma dan RatihHurriyati, Manajemen Corporate dan Strategi Pemasaran Jasa Pendidikan Fokus Pada Mutu dan Layanan Prima, (Bandung, Alfabeta, 2008), p.239-240.

4Buchari Alma dan Ratih Hurriyati, Manajemen Corporate dan Strategi Pemasaran Jasa Pendidikan Fokus Pada Mutu dan Layanan Prima, (Bandung, Alfabeta, 2008), p.239-240.

5 Andrias Harefa, Menjadi Manusia Pembelajar,(Jakarta: PT Kompas Media Nusantara, 2000),p.161.

6 Mulyadi, Kepemimpinan Kepala Sekolah dalam Mengembangkan Budaya Mutu, (Malang: UIN Maliki Press, 2010), p.v-vi.

7 E. Mulyasa, Menjadi Kepala Sekolah Profesional alam Konteks Menyukseskan MBS dan KBK (Bandung: Remaja Rosda Karya, 2003), p.98. 
leadership patterns are good in order to improve the schools quality, especially for teachers, 8 cooperation with various parties related to education programs in schools. responsibility for the achievement of the goals of school education by improving the professionalism of educational staff and directing the improvement of learning achievement of learners.9

Since the construct at 1986, Madrasah Aliyah Al-Mukmin Muhammadiyah Temanggung, Central Java, Indonesia is still classified as a developing madrasah. However, many students in the madrasah had good character habits as well as improvements in the academic field. This was influenced by the role of teachers, and teachers can showed their professional attitude by the headmaster influenced. The headmaster tried to make various educational and training programs that prepared from the teacher. This research was used qualitative research that focused to the leadership of the head madrasah based-quality in Madrasah Aliyah Al-Mukmin. The study was conducted in February 2018.

\section{The Concept of Leadership-Based Quality}

Leadership is an important factor in determining of the goals' achievement that have been set. Leadership is the central point and policy manufacturer of the activities in order to achieve the organization goal. Leadership is the process of directing and influencing work related activities to group members. This definition contains three important implications: (1) Leadership involves others; whether subordinates or followers. (2) Leadership involves power distribution between leaders and member share balance to take up the members that have no power. (3) The ability is use difference some forms of power to influence the behavior of followers in several ways. 10

Kotter (1997) argues that, leadership is a set of processes that primarily intended in creating an organization or adjust for

8 Mulyasa, Menjadi Kepala Sekolah Profesional, (Bandung: PT Remaja Rosdakarya, 2007), p.90.

9 E. Mulyasa, Menjadi Guru Professional Menciptakan Pembelajaran Kreatif dan Menyenangkan, (Bandung: Remaja Rosdakarya Ofset, 2007), p.16.

10 Nurkolis, Manajemen Berbasis sekolah, (Jakarta : PT Gramedia Widiasarana Indonesia, 2003,p.153. 
conditions that will be change. Leadership determines what the future should look like, leads to vision, and inspires to make it happen.11 There for, based on the above definitions, the leadership is a personal ability to influence others in cooperate, performance and collaboration to each other to achieve the common goals.

According to Edward Sallis, the primary role of educational leaders in creating a school culture based-quality, includes: (1) having a clear vision to integrated the organization quality, (2) having a clear commitment to improve the quality, (3) communicating the quality improvement, (4) ) guarantee the customer's necessary as the center of policy and work of the organization. (5) Ensure the accessibility of sufficient channels to accommodate the customer's opinions, (6) leads the development of staff. (7) Cautious and prudent to face the staff's guilt, (8) directing the innovation of organizations, (9) ensure clarity of the organizational structure, assigns the responsibilities and delivers the delegated are appropriately and maximally, (10) has a firm nature to exclude deviations from organizational culture, (11) builds a culture of active working groups, and (12) builds appropriate mechanisms to monitor and evaluate accomplishment.12

From the Management side, Joseph M. Juran stated leadership based-quality includes three managerial functions as follow:13

a) Quality planning; includes measures: customer identification, identify the customer necessary, developing products based on customer necessary, developing way and work processes to produce products that encounter or exceed the customer expectations, and transforming planning that results in action.

11Imam Machali dan Ara Hidayat, The Handbook of Education Management Teori dan Praktik Pengelolaan Sekolah/Madrasah di Indonesia,(Jakarta: Prenadamedia Group, 2016), p.83-84.

12Mulyadi, Kepemimpinan Kepala Sekolah Dalam Mengembangkan Budaya Mutu,(Malang: Uin Maliki Press, 2010), p.149.

13Fandy Tjiptono \& Anastasia Diana, Total Quality Management (Yogyakarta: ANDI. 2003), p.160 
b) Quality control; steps in this function are: actual performance evaluation, compare actual performance with goals, and take corrective action to overcome the existing performance differences.

c) Quality improvement; steps: establishing an infrastructure for continuous quality improvement, identifying processes or methods that require improvement, establishing teams responsible for specific improvement projects, and providing resources and training the team to repairand diagnose problems and identify causes, find the problem solving and making improvements to the problem.

\section{Madrasah Based-Quality}

Generally, the quality can be interpreted as animage and characteristic of the things or services that indicate an ability to satisfy all of necessary are expected or implied.14 Customer or user satisfaction, interest's achievement, customer or user belief, the increasing of expectation and customer satisfaction, measure quality's perception. 15

The definition of quality has a varied understanding. There are several opinions that explain about quality, among others:

1. According to Juran, quality is the suitability of product use (fitness for use) to meet customer needs and satisfaction.

2. According to Crosby, the quality is the conformance to requirement, which is in accordance with the required or standardized.

3. According to Deming, quality is conformity with market or consumer needs.

4. According to Feigenbaum, quality is full customer satisfaction.

According to Jerome S., Education based-quality, as Juran stated, the basis of Madrasah based-quality in developing programs and services is need of user necessary, like students and society. The society is referring to widely someone who use the

14 E. Mulyasa, Manajemen\&Kepemimpinan, p157-158.

15 Edward Sallis, Total Quality Management in Education, Manajemen Mutu Pendidikan, cetakan x, (Jogjakarta: Ircisod, 2011), p.7. 
graduate in business, educational institutions, government and other society, including the graduate's entrepreneurship. 16 Therefore, the education based-quality is cannot only be seen from the quality of the graduates, but also includes how educational institutions are able to meet customer requirements in accordance with applicable quality standards. In this case, the customers refer to teachers as internal customers and learners, parents, society, and graduates as external customers.17

There are internal school factors that contribute significantly to the education quality: a) teachers' welfare, b) teachers' skill, c) classroom facilities, and d) textbooks. While, the other factors are more detailed: a) students, especially concerning in their readiness and learning motivation, b) teachers, especially regarding to the professional skills, work morale (personal ability), and cooperation (social skills). c) Curriculum, especially concerning content relevance and operationalization of the learning process; d) funds, facilities and infrastructure, especially with regard to adequacy and effectiveness in supporting the learning process, e) communities (parents, graduate users and universities), especially regarding their participation in the development of educational programs in schools. 18

\section{The Leadership of the Head Madrasah-Based Quality in Madrasah Aliyah Al Mukmin}

The ability of the head madrasah, especially in the skills, related to the managerial and leadership skills influenced the educational quality. In order to carry out the head madrasah's leadership, the head has a target in achieving the vision and mission of the madrasah.

1. Realization of the Vision and Mission

The existence of madrasah's vision and mission could be a reference in acted or arranged work program. It was duty for the head to defined the vision and mission and communicated

16Mulyadi, Kepemimpinan ..., p.78.

${ }_{17}$ E. Mulyasa, Menjadi Kepala Sekolah Profesional (Bandung: Remaja Rosdakarya, 2007), p.226.

18Mudjamil Qomar, Manajemen Pendidikan Islam, ..., p.205-206. 
to the stakeholders and further embodied in the form of real action. Based on the results of interviews with a teacher. The researcher asked about the introduction of the vision of the mission and the effort to realize the vision mission of the head madrasah, he said: "The head in every opportunity was never forgot to convey the madrasah vision and asked all of the participant to support the achievement of the madrasah vision".19

Based on the interview above, showed that the head of the madrasah had a strong desire to realize the vision and mission of the madrasah. The head was diligent to socialize and share the vision with stakeholders. In addition, the head madrasah always planned activities that support the achievement of the vision and mission of the madrasah, and then realize the vision and mission into action. The head was often conducted evaluations to find out the shortcomings and seek solutions with the educators. He had demonstrated attitudes and behaviors were oriented towards the vision and mission of the madrasah. All activities that held in the madrasah were based and cause of the vision and mission.

\section{The Leadership of the Head Madrasah Based-Quality}

Good leadership is leadership that always strives to improve the quality of education. Similarly, the leadership of a good the head madrasah is always oriented towards improving the quality of madrasah, both academic and non-academic.

To achieve the madrasah based-quality, the first step taken by the head madrasah in build the quality culture. That was done by the head madrasah al-Mukminin to build a quality culture of madrasah. Quality culture of madrasah that applied in madrasah aliyah al-Mukmin, they were:

a. Always being a mukmin and muslim everywhere and anytime.

b. Always friendly in service.

c. Well-dressed, polite in speech and deeds. Because teachers were role models that had been imitated by their students.

19 Interview with Mr Muhtadi, Teacher in Madrasah Aliyah al Mukmin, at January $17^{\text {th }} 2018$ 
d. Behave and honest, trust, discipline, and akhlaq.

e. Having a high awareness in the work which based on the intention of worship and always strives to improve personal quality.

f. Having a broad scientific knowledge and professionalism and high dedication.

g. Having a high professionalism in carrying out administrative duties and adoring the work.

h. Creative, dynamic, and innovative in scientific development.

i. Having the ability of reasoning and sharpness in high thinking of scientific.

j. Behave and trustworthy manner, akhlaqul karimah and be role model to other academic community.

$\mathrm{k}$. Were highly discipline and always adhere to the teacher code of ethics.

1. Knowledgeable and wise in dealing and solving problems.

$\mathrm{m}$. Having future anticipatory capabilities and was proactive.

n. Always put interested to others above personal and sincere.20

As a leader, the head madrasah was able to demonstrate his ability to understand the conditions of the educational staff, to develop the educational staff programs, to make decisions with the education personnel in the madrasah, to communicate well with all teacher. To solve teachers problem; he was done with great caution, the head conveyed by using a delicate language to understand the feelings of the teachers. Besides, the head also concerned and provided motivational support in troubled teachers to repaire the problems properly.

Equally, in making decisions, the head was considered the situation and conditions at that time. Leadership type was used for giving the problems faced, situation and condition. The various problems that exist in the madrasah were solved by deliberation. Based on the interview with a teacher, he told that, he had been someone who accommodating problem. To solve a problem, he must seek the opinion of the subordinates. He

20 Interview with Mr. Makmun Pitoyo, Head Master in Madrasah Aliyah al Mukmin, at January $17^{\text {th }} 2018$ 
consulted many others to find the solution. Therefore, if any problem, the head madrasah was not immediately resolved quickly but considered to other things and asked other teacher's the opinion to solve the problem.

Coaching efforts by the head madrasah to teachers and employees were done with various kinds. To improve teacher performance, the head always motivates teachers in weekly meetings. Monitoring efforts also did not escape from his routine activities as a means to evaluate the activities of madrasah. In teaching and learning activities for example, it was not common for headmaster to control each class for looking that condition of the class and knowing the quality of learning by the teacher. When any problem or something that was ineffective, weekly meetings to find the solutions, and sometimes the problems will cover directly if the situation was terrible. The head madrasah has an appropriate strategy to empower educational personnel through cooperation, provided the educational personnel with the opportunity to improve their profession, and to encouraged the involvement all of the education personnel in various activities that support the madrasah program.

The communication that exists between the head madrasah and the colleague is very well. He often involves subordinates in every activity included the policies had been implemented. Some changes that have been applied for submitting to colleagues were clearly and accompanied of the goals achieved.21

The sume of important point can conclude to five principles there are (1). Always being a mukmin and muslim everywhere and anytime. (2). always friendly in service. (3). having a high professionalism in carrying out administrative duties and adoring the work. (4). Creative, dynamic, and innovative in scientific development, and (5). Behave and trustworthy manner, akhlaqul karimah and be role model to other academic community.

\section{Conclusion}

The successful implementation of madrasah head leadership in managing educational institutions was influenced by the ability of the head madrasah in planned, organized, provided direction,

21 Interview with Mr Bisron, At Temanggung, at January $17^{\text {th }} 2018$ 
and supervised all of the education activities in madrasah. The madrasah successful in achieving the good quality of education was determined by the leadership role of the head madrasah. The important point can conclude to five principles there are (1). always being a mukmin and muslim everywhere and anytime. (2). always friendly in service. (3). Having a high professionalism in carrying out administrative duties and adoring the work. (4). Creative, dynamic, and innovative in scientific development, and (5). Behave and trustworthy manner, akhlaqul karimah and be role model to other academic community.

\section{Bibliography}

Alma Buchari, dan Ratih Hurriyati, 2008. Manajemen Corporate dan Strategi Pemasaran Jasa Pendidikan Fokus Pada Mutu dan Layanan Prima, Bandung: Alfabeta.

Bisron , 2018, Interview, Public Figure at Temanggung,

Fatah, Nanang, 1999. Landasan Manajemen Pendidikan, Bandung: Remaja Rosda Karya.

Harefa, Andrias, 2000. Menjadi Manusia Pembelajar, Jakarta: PT Kompas Media Nusantara.

Machali, Imam dan Ara Hidayat, 2016. The Handbook of Education Management Teori dan Praktik Pengelolaan Sekolah/Madrasah di Indonesia,Jakarta: Prenadamedia Group.

Muhtadi, 2018, Interview, Teacher in Madrasah Aliyah al Mukmin

Mulyadi, 2010. Kepemimpinan Kepala Sekolah dalam Mengembangkan Budaya Mutu, Malang: UIN Maliki Press.

Mulyasa, E, 2003. Menjadi Kepala Sekolah Profesional alam Konteks Menyukseskan MBS dan KBK, Bandung: Remaja Rosda Karya.

Mulyasa, E, 2012.Manajemen \& Kepemimpinan Kepala Sekolah, Jakarta: Bumi Aksara. 
Nurkolis, 2003. Manajemen Berbasis sekolah, Jakarta: PT Gramedia Widiasarana Indonesia.

Pitoyo, Makmun, 2018, Interview, Head Master in Madrasah Aliyah al Mukmin

Sallis, Edward, 2011. Total Quality Management in Education, Manajemen Mutu Pendidikan, Jogjakarta: Ircisod.

Tjiptono, Fandy \& Anastasia Diana, 2003. Total Quality Management Yogyakarta. 